Editorial

\title{
A View from the Inside: The Dawning Of De-Westernization of CEE Media and Communication Research?
}

\author{
Epp Lauk \\ Department of Communication, University of Jyväskylä, 40014 Jyväskylä, Finland; E-Mail: epp.lauk@jyu.fi
}

Submitted: 22 December 2015 | Published: 29 December 2015

\begin{abstract}
The Editorial outlines some characteristics of the development of the Central and Eastern European (CEE) media and communication scholarship during the past 25 years. In the majority of CEE countries, the media and communication research was re-established after the collapse of communism. Since then, a critical mass of active scholars has appeared who form an integral part of the larger European academia. A gradual integration of East and West perspectives in media and communication research is taking place along with moving away from the barely West-centred approach, and utilizing the research done by CEE scholars. Certain 'de-westernization' and internationalization of the research in terms of theoretical and methodological frameworks is depicted.
\end{abstract}

\section{Keywords}

Central and Eastern Europe; media systems; media change; CEE media and communication scholarship; de-westernization

\section{Issue}

This editorial is part of the special issue "Turbulences of the Central and Eastern European Media", edited by Epp Lauk (University of Jyväskylä, Finland).

(C) 2015 by the author; licensee Cogitatio (Lisbon, Portugal). This article is licensed under a Creative Commons Attribution 4.0 International License (CC BY).

The collapse of communist regimes and dissolution of the Soviet Union in the late 1980s and early 1990s opened up a new, large and compelling field of media and communication scholarship-media transformation and democratization in Central and Eastern Europe (CEE). Like the other fields of social sciences in CEE countries, media and communication studies literally had to be re-established in the early 1990s. No wonder then that in the early stages, scholarly discussion of the most crucial issues (e.g., new ownership patterns, formation of public service media, new technologies, professionalization of journalism etc.) largely followed the lines of Western European and American conceptualisations. These, however, appeared insufficient in explaining the peculiarities of CEE media development. For instance, the efforts at exporting the philosophy and elements of the liberal (Anglo-American) model of journalism were not successful in CEE countries, although this model has been generally accepted by media practitioners and theorists as the dominant ideal of a responsible and professional journalism.
Hallin and Mancini (2004) did not include CEE countries in their comparative media analysis. Their typology is based on an assumption of relatively stable processes of societal and media development. Their models do not, therefore, embrace rapidly changing media systems, although many elements of their analysis are applicable. As a result of comparative research it has become obvious that regardless of a generally similar framework-democratic government, market economy, and freedoms of the press and expressionmedia systems in these countries have developed along a variety of trajectories.

The international scholarly debates have recognized "an obviously existing disjuncture between theoretical approaches and systems of analysis predominantly rooted in North-Western academia and complex media realities that go beyond the narrow scope of Western experience" (Grüne \& Ulrich, 2012, p. 1; see also Curran \& Park, 2000). It has become obvious that the media "in democratising countries is an exercise of a different quality than the study of mass media in established 
democracies of the West, in which media studies originated" (Jebril, Stetka, \& Loveless, 2013, p. 2).

A quarter of a century of development of CEE media and communication scholarship has led to a significant change in the direction of the research perspectives: from West-to-East towards East-to-East and Eastto-West.

The first decade of CEE media research produced two kinds of studies that can generally be labelled as descriptive comparisons. First, the collections of singlecountry studies that describe a set of aspects of media change in each country, such as market conditions for the print and broadcasting media; ownership structures; legal regulation; media consumption; audiences; aspects of professionalization etc. (Paletz \& Jakubowicz, 2003; Paletz, Jakubowicz, \& Novosel, 1995; Vihalemm, 2002). Second, approaches that attempt at conceptualizing and theorizing the media change by comparing particular phenomena in different countries. For example, the development of public broadcasting across certain CEE countries; the conditions of media freedom; state media policy; structural development of media systems; media and civil society etc. (cf. Downing, 1996; Sparks \& Reading, 1998;Splichal, 1994; Sükösd \& Bajomi-Lázár, 2003). The normative understanding of the role and functions of the media in a democratic society dominated as the departure point for explaining the differences and similarities between the countries. The realities of the emerging democracies in CEE, however, deviated significantly from those in established democracies, and the research soon led to the conclusion that the transforming societies construct their unique media systems in a manner that cannot be entirely explained using only the 'western' perspective. For example, the role of cultural and other contextual factors appeared to be more significant than had been assumed. It also became apparent that the issue about the role of the media in societal change remained insufficiently explored. As Jebril et al. (2013, p. 10) demonstrate, from the mid-2000s, the evolution of the scholarship continued towards "a more systemic approach, and comparative perspective, often inspired by Hallin and Mancini's (2004) seminal book on comparative media and politics...and discussing particular aspects of media system transformation in the context of broader processes of Europeanisation and globalisation". From this perspective, for example, Greskovits suggests three distinct varieties of capitalism emerged in CEE societies instead of one: 1) the neoliberal, 2) the embedded neoliberal, and 3) the neocorporatist type, which all resulted in different types of media systems (Greskovits, 2015). Based on the analysis of the indicators of the advancement of societal transformations (the level of media politicization, economic development and degree of media commercialization, freedom of expression, access to the internet) Dobek-Ostrowska defines four models of media and politics in CEE
(Dobek-Ostrowska, 2015). She classifies all 21 postcommunist CEE countries into the Hybrid Liberal (7 states), the Politicized Media (5 states), the Media in Transition (7 states) and the Authoritarian models (2 states). All the countries of the Hybrid Liberal model ${ }^{1}$ have joined the EU and have the highest rankings in the Democracy Index and the Press Freedom Index, and have the highest GDP among the CEE countries. This model is described as the most stable among the four models. The Politicized Media model applies to Bulgaria, Croatia, Hungary, Romania and Serbia, with high political parallelism, high politicization of public broadcasting and control over the PSB by political actors, and economic stagnation. The Freedom House classifies these countries as 'partly free'. The Media in Transition Model is typical to Moldova, Macedonia, Montenegro, Albania, Kosovo, Bosnia and Herzegovina and Ukraine. All of them are in the phase of transition towards democracy and the primary stage of media reform. Weak democratic standards are accompanied by very low journalistic professionalism. The Authoritarian model includes Belorussia and Russia. They are 'nonfree' countries according to the Press Freedom Ranking of 2014, and the media in both countries are instrumentalized by political elites (Dobek-Ostrowska, 2015, pp. 26-35). Dobek-Ostrowska's 'inside perspective' of characterising media systems of CEE countries adds a new dimension to traditional normative approaches and deserves further discussions.

The collections of the 2010s have added valuable contribution to the systemic approach and analytical comparison in CEE media research (esp. Dobek-Ostrowska \& Glowacki, 2015; Dobek-Ostrowska, Glowacki, Jakubowicz, \& Sükösd, 2010; Downey \& Mihelj, 2012; Glowacki, Lauk, \& Balčytiene, 2014; and Zielonka, 2015).

In addition to (collective) publications, the international co-operation of scholars has significantly contributed to the development of the CEE scholarship. In shifting the direction of the research perspective, a European collaborative network in 2005-2009, COST A30 played an important role. The network was called "East of West: Setting a New Central and Eastern European Media Research Agenda". The project was a good example of integration of East and West perspectives in media and communication research moving away from West-centred approach, and theoretically and methodologically utilizing the research done by CEE scholars. This was, in all likelihood, the first network that brought together media and political communication researchers from 13 CEE countries, and boosted the development of their scholarship. Today, researchers from 12 CEE countries participate in the global project called Worlds of Journalism Study ${ }^{2}$, which investigates the de-

\footnotetext{
1 The Czech Republic, Estonia, Latvia, Lithuania, Poland, Slovakia and Slovenia.

2 http://www.worldsofjournalism.org/index.htm
} 
velopment of journalism cultures around the globe.

From the viewpoint of the history of CEE media and communication scholarship, the first regional meeting in Poland, in 2008, was a defining moment. The first Polish-Czech-Slovak Forum on Political and Communication Sciences demonstrated that the community of researchers had acquired the critical mass necessary to advance CEE scholarship on key issues and the trends of these societies and their media. Since 2008, the Central and Eastern European Media and Communication Conferences have become regular events and are increasingly attracting scholars from around the world. The $8^{\text {th }}$ conference took place in Zagreb in 2015.

In 2010, European Communication Research and Education Association established a Central and East European Network to engage more regional scholars into the activities of ECREA and promote research projects and fieldwork carried out at the CEE Universities and Departments, as well as facilitating communication and cooperation between both institutions and scholars based in the 'West' and the 'East'.

Within recent decades, a number of new communication and media research journals (including eight international ones) have been established in CEE countries, which definitely have enhanced the possibilities of the CEE scholars to present their work to larger national and international audiences ${ }^{3}$. None of the languages of CEE countries is sufficiently widespread to serve as the academic lingua franca for any region. The main option is to publish in English. Scholarly discourse in national languages, however, will not develop without publications in those languages. Bilingual publishing seems to be a rather popular practice in the journals, simultaneously serving both purposes: enabling international visibility and developing national scientific discourse.

The special issue of Media and Communication journal is an additional proof of the ability of CEE scholarship to add fresh viewpoints to the media and communication research internationally. The authors (15 of 16) represent the community of CEE media and communication researchers, who discuss in their articles several 'universal' issues of media development (ownership, ethics, media policy, status of public service media, media literacy, information culture) from the perspectives of their own countries. Along with a broader issue of the role of academic scholarship in journalism cultures in CEE, Czech and Slovak council newspapers and religious radio stations in Poland and Hungary are comparatively discussed. The Estonian ex-

\footnotetext{
${ }^{3}$ Among them, the best known and most cited are Javnost/The Public (published in Slovenia), Central European Journal of Communication (published in Poland), Medijska Istraživanja/ Media Research (published in Croatia), Medialni Studia/Media Studies (published in the Czech Republic) and Media Transformations (Lithuania).
}

ample throws light on news organizations' search for ways of making online news profitable.

The expansion of the scope and diversification of the theoretical and methodological approaches of the CEE media and communication research clearly reflect its advancement towards a distinct field of scholarship. Simultaneously, it forms an integral part of a broader European research agenda. 'De-westernization' does not mean "a rejection of Western theories and paradigms, but rather their critical revision and improvement through an openness for flexible integration of 'peripheral paradigms'”, as Grüne and Ulrich $(2012$, p. 1) emphasize. Even a rather cursory view on the 25 years of the CEE media and communication scholarship confirms the relevance of this statement.

\section{Conflict of Interests}

The author declares no conflict of interests.

\section{References}

Curran, J., \& Park, M.-J. (Eds.) (2000). De-Westernizing media studies. Routledge.

Dobek-Ostrowska, B. (2015). 25 years of communism: Four models of media and politics in Central and Eastern Europe. In B. Dobek-Ostrowska \& $\mathrm{M}$. Glowacki (Eds.), Democracy and media in Central and Eastern Europe 25 years on (pp. 11-46). Frankfurt am Main: Peter Lang.

Dobek-Ostrowska, B., \& Glowacki, M. (Eds.) (2015). Democracy and media in Central and Eastern Europe 25 years on. Frankfurt am Main: Peter Lang.

Dobek-Ostrowska, B., Glowacki, M., Jakubowicz, K., \& Sükösd, M. (Eds.) (2010). Comparative media systems. European and global perspectives. Budapest and New York: CEU Press.

Downey, J., \& Mihelj, S. (2012). Central and Eastern European media in comparative perspective. Politics, economy and culture. Surrey, UK: Ashgate.

Downing, J. D. H. (1996). Internationalizing media theory. Transition, power, culture. London, Thousand Oaks and New Dehli: Sage.

Glowacki, M., Lauk, E., \& Balčytiene, A. (Eds.) (2014). Journalism that matters. Views from Central and Eastern Europe. Frankfurt am Main: Peter Lang.

Greskovits, B. (2015). Capitalist diversity and the media. In J. Zielonka (Ed.), Media and politics in new democracies. Europe in a comparative perspective (pp. 5872). Oxford: Oxford University Press.

Grüne, A., \& Ulrich, D.-C. (2012). Editorial: (De-) Westernizing media and journalism studies: Demarcating, transcending and subverting borders. Global Media Journal, 2(2). Retrieved from www.global mediajournal.de

Hallin, D. C., \& Mancini, P. (2004). Comparing media systems. Three models of media and politics. Cam- 
bridge: Cambridge University Press.

Jebril, N., Stetka, V., \& Loveless, M. (2013). Media and democratisation: What is known about the role of mass media in transitions to democracy. Oxford: Reuters Institute for the Study Journalism.

Paletz, D. L., \& Jakubowicz, K. (Eds.) (2003). Business as usual. Continuity and change in Central and Eastern European media. Cresskill, NJ: Hampton Press Inc.

Paletz, D. L., Jakubowicz, K., \& Novosel, P. (Eds.) (1995) Glasnost and after. Media and change in Central and Eastern Europe. Cresskill, NJ: Hampton Press Inc.

Sparks, C., \& Reading, A. (1998). Communism, capitalism and the mass media. London: Sage.

Splichal, S. (1994). Media beyond socialism: Theory and practice in East Central Europe. Boulder: Westview Press.

Sükösd, M., \& Bajomi-Lázár, P. (Eds.) (2003). Reinventing media: Media policy reform in East-Central Europe. Budapest: Central European University Press.

Vihalemm, P. (Ed.) (2002). Baltic media in transition. Tartu: Tartu University Press.

Zielonka, J. (Ed.) (2015). Media and politics in new democracies. Europe in a comparative perspective. Oxford: Oxford University Press.

\section{About the Author}

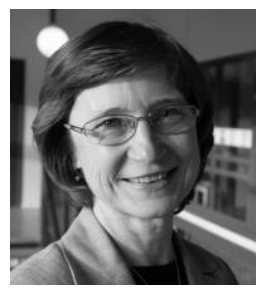

\section{Dr. Epp Lauk}

Epp Lauk is Professor of Journalism and Head of the Department of Communication at the University of Jyväskylä, Finland. Her research interests and publications include media development in Eastern and Central European new democracies, the history and culture of journalism and its professionalization in national and international perspective. She is Board member of the European Communication Research and Education Association, co-chair of the International Association for Media and Communication Research History Section and chair of the Estonian Press Council (ASN). 